\title{
Factors Affecting Tree Husbandry and Woodlots Establishment in Kilimanjaro Region, Tanzania
}

\author{
Revocatus Petro ${ }^{*}$, Francis Laswai ${ }^{2}$, Mohammed Mijai ${ }^{1}$, \\ Geofrey Nyaradani ${ }^{1}$, Chelestino Balama ${ }^{2}$ \\ ${ }^{1}$ Tanzania Forestry Research Institute, Moshi, Tanzania \\ ${ }^{2}$ Tanzania Forestry Research Institute, Morogoro, Tanzania \\ Email: "
}

Received 11 May 2015; accepted 22 August 2015; published 25 August 2015

Copyright (C) 2015 by authors and Scientific Research Publishing Inc.

This work is licensed under the Creative Commons Attribution International License (CC BY). http://creativecommons.org/licenses/by/4.0/

(c) (i) Open Access

\section{Abstract}

The study on assessment of factors affecting tree husbandry and woodlots establishment was carried out between September and November 2014 in all seven districts of Kilimanjaro region, namely Hai, Siha Rombo, Mwanga, Same, Moshi Rural and Moshi Municipal Council (MMC). A purposive sampling design was employed whereby two wards per district were selected for the study. Household questionnaire survey was used in data collection. Results show that, factors affecting tree husbandry and woodlots establishment in Kilimanjaro region are gender, livelihood activities, access and ownership/land tenure, cultural factors, legal issues and by-laws insisting people to plant trees. About $32.4 \%, 32.4 \%$ and $30 \%$ of all respondents own land with size of 1.0 acre and below, 1.1 - 2.0 and 2.1 - 5.0 acres respectively. Respondents from Hai (55.3\%), Same (26.3\%), Rombo (11\%) and MMC (8\%) agreed that cultural issues affect tree husbandry. About $1 \%, 23 \%$, $30 \%$ and $40.8 \%$ of respondents in Siha, Same, Hai and Rombo districts respectively agreed that some of by-laws insist people to plant trees on their environments. None of the respondents from any district reported labour availability to be one of the factors affecting tree husbandry. Other factors reported to affect tree husbandry in Kilimanjaro region were capacity building in tree planting and tending, insect pests, diseases and climate change. Formulation of by-laws which insist on tree planting and limit land degradation is recommended at village level. Every piece of land should be planned and used sustainably including area for tree planting. Custom and norms which inhibit women to plant trees should be prohibited through capacity building.

\section{Keywords}

Socio-Cultural Factors, Tree Husbandry, Woodlots, Kilimanjaro, Tanzania

\footnotetext{
${ }^{*}$ Corresponding author.
}

How to cite this paper: Petro, R., Laswai, F., Mijai, M., Nyaradani, G. and Balama, C. (2015) Factors Affecting Tree Husbandry and Woodlots Establishment in Kilimanjaro Region, Tanzania. Open Journal of Soil Science, 5, 169-180. 


\section{Introduction}

Tanzania has a total area covering about $945,000 \mathrm{~km}^{2}$ of which 33.5 million ha are forests and woodlands [1]. About 13 million ha have been gazetted as forest reserves. The main forest types are the extensive miombo woodlands in lowland areas across the central and southern parts of the country, the Acacia woodlands in the northern regions, the coastal forest/woodland mosaic in the east, mangrove forests along the Indian Ocean shoreline, and closed canopy forests on the ancient mountains of the Eastern Arc in the east [2]. Of these various forest types, 14.3 million ha are found within gazetted Forest Reserves, 2.5 million ha are proposed as Forest Reserves, and about 2 million ha are in Game Reserves or National Parks [2] [3]. The total area of forest plantations is estimated to be between 190,000 and 250,000 ha, made up of 85,000 ha of state managed industrial plantations, about 40,000 ha of private companies industrial plantations, and 80,000 to 140,000 ha of village and farm plantations [4].

Kilimanjaro region covers an area of $13,209 \mathrm{~km}^{2}$ or 1.4 percent of the area of the entire Tanzania Mainland out of which $2181.38 \mathrm{~km}^{2}$ are forest reserves, located mainly on high altitudes as water catchments forests [5]. Almost the entire region's population of 1.64 million by 2012 census [6] relies upon biomass fuels of firewood, charcoal, agricultural residues and biogas for domestic heating and cooking. However, wood fuel (firewood and charcoal) accounts for about 95\% of the total energy consumed in the region [7]. Wood fuel is mainly used for cooking, water heating, house heating and lighting. Households are the most important category in wood energy consumption while the second highest consumer of wood fuel are the cottage industries which include brick making, tobacco curing, fish smoking, and bakeries [8]. Supply of the fuel wood in Kilimanjaro region is mainly from the thickets and bushes estimated to cover about $1000 \mathrm{~km}^{2}$ of the land. The major tree species found in these forests falls into three generic groups, which are Acacias, Albizias and Combretums [9]. Trees like Melicia excelsa (mvule) and Dalbergia melanoxylon (mpingo) are also found in lower part of the region. Many important commercial trees in Kilimanjaro have been harvested with no programs for replanting which has led to widespread of deforestation which in turn causing erosion of the soil, then loss of soil fertility, loss of wildlife habitat and loss of biodiversity. Kilimanjaro communities are suffering from the results of these misfortunes and unsustainable land management. Agricultural activities all over the region have been affected due to shortage of rainfall and high temperature prevailing for quite long causing seasonal rivers and streams to dry out completely. Women, who traditionally collect firewood, spend longer hours to secure the same amounts of wood and many people are now using their precious hard-earned cash to purchase wood. The population increase in the region from 652,772 in 1967 to 1,640,087 in 2012 [5] [6] has caused an increase in competition of land use form for production of agricultural crops, livestock husbandry and tree husbandry.

Several institutions and individuals have been trying to reforestate the deforestated and degraded areas in order to rescue the current situation. Fast growing fuel wood, fruits, medicine and lumber producing tree species have been introduced to help families from spending time and money on these domestic products. Despite of all efforts made to rehabilitate the lost trees/forests in the region, it is not known as to why majority of the people in the region do not have tree woodlots. Therefore, this study aimed at identifying factors affecting tree husbandry and woodlot establishment in Kilimanjaro region. The results from this study will be used in making recommendations which will lead to overcome factors affecting tree planting in Kilimanjaro Region.

\section{Methods}

\subsection{Description of the Study Areas}

\subsubsection{Location}

The study was conducted in Kilimanjaro region, which is divided into seven districts, namely Hai, Siha, Rombo, Mwanga, Same, Moshi Rural and Moshi Municipality. Kilimanjaro region is located in the north eastern part of Tanzania Mainland. It lies between latitudes $2^{\circ} 25^{\prime}$ and $4^{\circ} 15^{\prime}$ south of the Equator and between longitude $36^{\circ} 25^{\prime} 30^{\prime \prime}$ and $38^{\circ} 10^{\prime} 45^{\prime \prime}$ east of Greenwich. The region has a common border with Kenya in the north, Tanga region in the southeast and Manyara and Arusha regions to the south and west (Figure 1).

\subsubsection{Climate and Soils}

In Kilimanjaro region, there are two rainy seasons and two dry seasons. Rainfall starts from September to November as short rainy season and March to May as long rainy season. The dry season starts from December to January and then from July to August every year. The mean annual rainfall varies from $500 \mathrm{~mm}$ in the lowlands 


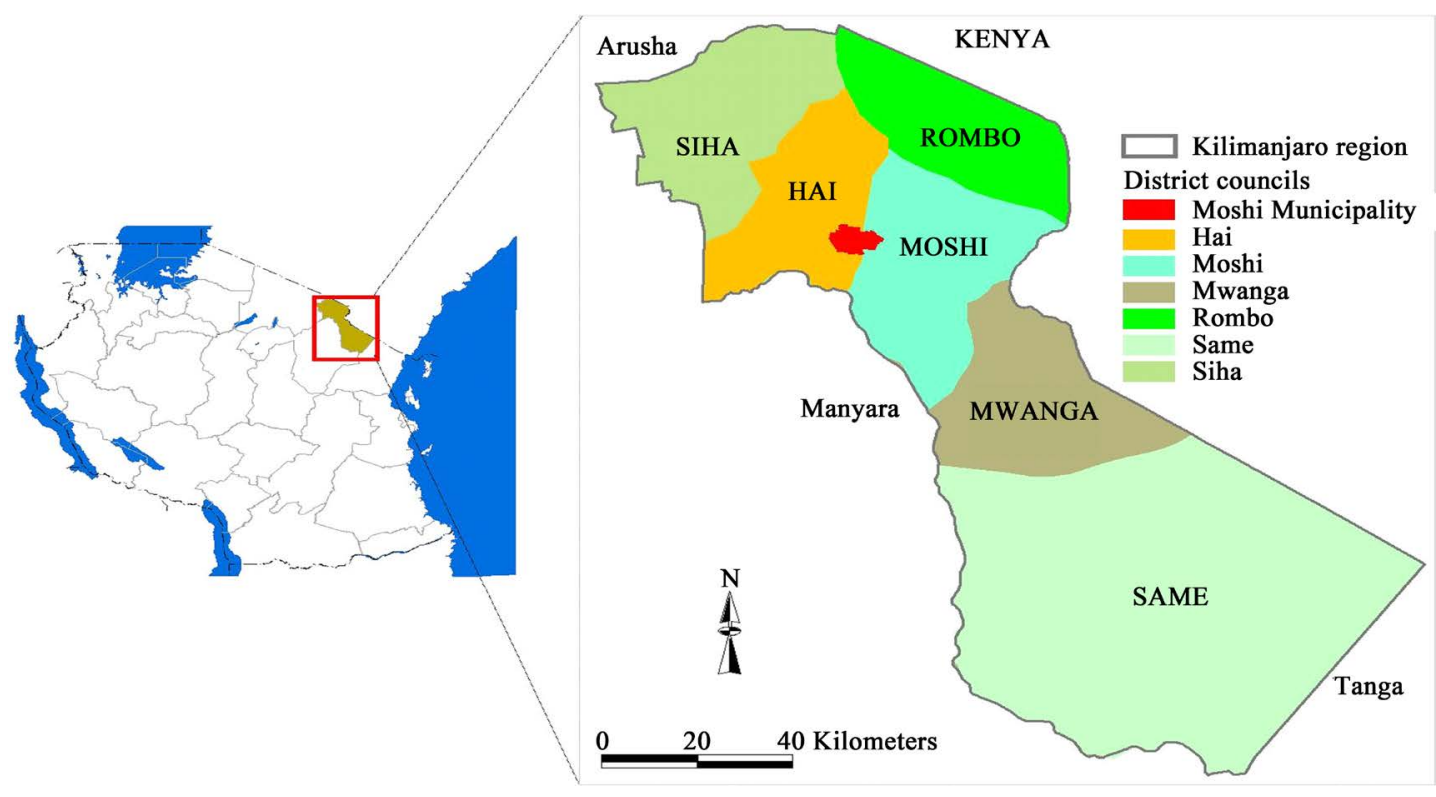

Figure 1. Location of Kilimanjaro region, Tanzania [10].

to over $2000 \mathrm{~mm}$ in highland areas located over 1600 meters above sea level. The average minimum and maximum temperatures of the region are $15^{\circ} \mathrm{C}$ and $30^{\circ} \mathrm{C}$ respectively in the mountainous areas. However, temperature goes up as far as $40^{\circ} \mathrm{C}$ in the lowlands during hot period. Soils of the region vary; there are alluvial soils in lower Moshi and areas near Pangani and Mkomazi rivers. Areas in the foot of mountain ranges of Pare comprise colluvial soils and in the highland areas of Mount Kilimanjaro the soils are andosols, rich in nutrients, and are generally deep to very deep loam soil reddish in colour. Forest soils are loam with full of litter and the $\mathrm{pH}$ is 4 4.6 and less in this area [11] [12].

\subsection{Data Collection}

\subsubsection{Sampling Design}

A purposive sampling design was employed whereby two wards per district were selected. This method is a non probability sampling technique where by an experienced individual selects the sample based on his/her experience to judge the appropriate characteristics required for the sample. The criteria used included 1) presence of the sustainable land management (SLM) project, 2) topography of the area (upper, medium, and lower slopes so as to capture different weather conditions) and 3) household involvement in tree planting

\subsubsection{Socio-Economic Survey}

Socio-economic data were collected through questionnaire survey that intended to get information at household level independently. The questionnaire was structured and open-ended (Appendix 1). The structured questions were employed on issues where a specific range of known responses was expected. Such questions allow easier interpretation and analysis than open-ended questions. On the other hand, the open-ended questions were included so as to allow interviewees to construct their own version of experiences because the explanatory power of structured questions is limited [13].

\subsubsection{Data Analysis}

Quantitative data from questionnaire surveys were coded to facilitate their entry into the computer. They were analysed using the Statistical Package for Social Sciences (SPSS) Computer Programme Version 16 software and results were presented. Data on gender was aggregated as males and females for each district. Proportion (percentage) of each district was determined in relation to the total for the region. Education was grouped into primary, secondary, college and informal levels. Livelihood activities were grouped into crop production, livestock, crop and livestock production, business and employee \& others. Numbers of trees owned by respondents were grouped in to five categories mainly; 1 - 50, 51 - 100, 101 - 200, 201 - 500 and >500 trees. Size of the land 
owned by respondents were classified in to four classes mainly; $\leq 1.0,1.1-2.0,2.1-5.0$ and $\geq 5.1$ acres. Percentages of each education level, livelihood activity, trees category, land classes were determined in relation to the total of all groups in the region. Proportions of cultural issues, legal issues, insects and diseases data per district were determined in relation to the total for the region. However, the number of respondents differed from one section to another as not all respondents answered all questions in the questionnaire.

\section{Results and Discussion}

\subsection{Characteristics of the Respondents}

\subsubsection{Gender}

The results in Table 1 show that, the majority of the interviewed respondents (56.6\%) were males and the rest (43.4\%) were females. This implies that most of the households interviewed were male headed. The same situation has been observed in other studies conducted in other areas, e.g. in studies conducted in Morogoro Rural and Mufindi Districts male headed households were 73\% and 62.5\% respectively [14] [15]. Gender has an influence on tree husbandry since some of the activities are performed by men only while others by women and when women perform activities which are associated with men, then they are doing them on behalf of men not on their own behalf. Generally, majority of the activities in tree growing are for male dominated except weeding and watering which are performed by women in most of the Districts in Kilimanjaro region. Therefore, gender affects tree husbandry in the region.

\subsubsection{Education Level of the Respondents}

Majority of the respondents (72.3\%) have attained primary level education (Table 2). However, few individuals

Table 1. Number of respondents and percentage distribution by gender, Kilimanjaro region, Tanzania.

\begin{tabular}{ccccc}
\hline Districts & \multicolumn{2}{c}{ Gender } & Total Respondents & \% of Total Sample \\
\cline { 2 - 3 } & Male & Female & 54 & 15.1 \\
Hai & 36 & 18 & 59 & 16.5 \\
Siha & 31 & 28 & 51 & 14.3 \\
Same & 27 & 24 & 60 & 16.8 \\
Mwanga & 32 & 28 & 60 & 16.8 \\
Rombo & 36 & 21 & 48 & 13.4 \\
Moshi Rural & 27 & 12 & 25 & 7.1 \\
Moshi Municipal & 13 & 155 & 357 & 100 \\
Total & 202 & 43.4 & 100 & \\
\hline
\end{tabular}

Table 2. Number of respondents and percentage distribution by education level, Kilimanjaro region, Tanzania.

\begin{tabular}{|c|c|c|c|c|c|}
\hline \multirow{2}{*}{ District } & \multicolumn{4}{|c|}{ Education Level } & \multirow{2}{*}{ Total } \\
\hline & Primary & Secondary & College & Informal & \\
\hline Hai & 34 & 10 & 5 & 2 & 51 \\
\hline Siha & 37 & 12 & 1 & 8 & 58 \\
\hline Same & 44 & 5 & 0 & 1 & 50 \\
\hline Mwanga & 46 & 11 & 0 & 2 & 59 \\
\hline Rombo & 46 & 9 & 2 & 1 & 58 \\
\hline Moshi Rural & 27 & 19 & 0 & 0 & 46 \\
\hline Moshi Municipal & 17 & 6 & 2 & 0 & 25 \\
\hline Total & 251 & 72 & 10 & 14 & 347 \\
\hline$\%$ & 72.3 & 20.8 & 2.9 & 4.0 & 100 \\
\hline
\end{tabular}


(20.8\%) have attained secondary education and minority $2.9 \%$ and $4.0 \%$ have attained college education and informal education respectively. Despite the low level of education observed in this study, majority of the respondents know how to plant and manage trees. This is probably due to the fact that in Tanzania, tree planting and management are taught even in primary schools. This is in contrary to the report [16] that people with high level of education stand a good chance of conserving natural resources.

\subsubsection{Livelihood Activities of the Respondents}

A combination of crop and livestock production was the most important (51\%) economic activity followed by crop production alone (39\%) (Table 3). The main cultivated crops were banana and coffee which are normally intercropped with trees. Other crops were maize, potatoes, vegetables, cowpeas, beans and sunflower. Coffee which was the main cash crop has been clear felled due to downfall of world prices. The removal of coffee tree affects much of tree husbandry in Kilimanjaro since shade trees were also removed to allow light intensity to other agricultural crops. Livestock keeping was the least important livelihood activity because of shortage of grazing land in highland areas of Kilimanjaro. Animals kept include cattle, goats, pork and poultry and were confined in a zero grazing system. The presence of livestock in a zero grazing system forced people to plant tree which are used as fodder. Livestock keeping in highland areas contribute positively in tree planting. Therefore livelihood activities affects tree husbandry in Kilimanjaro region.

\subsection{Factors Affecting Tree Husbandry and Woodlot Establishment}

\subsubsection{Access and Ownership/Land Tenure}

About 32.4\%, 32.4\% and 30\% of all respondents owned land with size of 1.0 acre and below, 1.1 - 2.0 and 2.1 5.0 acres respectively (Table 4). The number of respondents who owned land in Moshi Municipal was very few compared to other districts because most of the respondents are living in rented houses hence they have no land. Siha and Same were the leading districts by having large number of respondents who reported to own land with

Table 3. Number of respondents and percentage distribution by livelihood activities, Kilimanjaro region.

\begin{tabular}{|c|c|c|c|c|c|c|}
\hline \multirow{2}{*}{ District } & \multicolumn{5}{|c|}{ Livelihood Activities } & \multirow{2}{*}{ Total } \\
\hline & Crop production & Livestock & Crop \& Livestock Production & Business & Employee \& Others & \\
\hline Hai & 24 & 5 & 19 & 4 & 0 & 52 \\
\hline Siha & 36 & 0 & 20 & 2 & 0 & 58 \\
\hline Same & 17 & 0 & 32 & 1 & 1 & 51 \\
\hline Mwanga & 13 & 2 & 41 & 1 & 1 & 58 \\
\hline Rombo & 17 & 1 & 36 & 3 & 0 & 57 \\
\hline Moshi Rural & 18 & 1 & 22 & 1 & 4 & 46 \\
\hline Moshi MC & 11 & 1 & 6 & 6 & 0 & 24 \\
\hline Total & 136 & 10 & 176 & 18 & 6 & 346 \\
\hline$\%$ & 39.3 & 2.9 & 50.9 & 5.2 & 1.7 & 100 \\
\hline
\end{tabular}

Table 4. Number of respondents in each land-size category, Kilimanjaro region, Tanzania.

\begin{tabular}{|c|c|c|c|c|c|}
\hline \multirow{2}{*}{ District } & \multicolumn{4}{|c|}{ Number of Respondents by Land Size (acre) Category } & \multirow{2}{*}{ Total } \\
\hline & $\leq 1.0$ & $1.1-2.0$ & $2.1-5.0$ & $\geq 5.0$ & \\
\hline Hai & 29 & 14 & 9 & 0 & 52 \\
\hline Siha & 16 & 19 & 21 & 3 & 59 \\
\hline Same & 4 & 7 & 28 & 11 & 50 \\
\hline Mwanga & 23 & 20 & 15 & 1 & 59 \\
\hline Rombo & 20 & 22 & 16 & 0 & 58 \\
\hline Moshi Rural & 13 & 19 & 12 & 3 & 47 \\
\hline Moshi MC & 5 & 9 & 0 & 0 & 14 \\
\hline Total & 110 & 110 & 101 & 18 & 339 \\
\hline$\%$ & 32.4 & 32.4 & 30 & 5.2 & \\
\hline
\end{tabular}


size of 2.1 - 5.0 acres (Table 4). Correspondingly, Same had the highest number of respondents who own land with size of above 5.0 acre. In the highland areas of Kilimanjaro, a family owns a land of an average of 0.5 of a hectare (1.25 acres) while in lowland area a family owns 1.5 hectares (3.75 acres) [5] and this land especially in the coffee belt or the Chagga home gardens is regulated by customary law, where transfer or change of ownership is ruled by inheritance patterns (ownership passing to sons). Environmental degradation in Kilimanjaro region seems to be increasing due to poor land husbandry practices such as lack of use of soil-erosion control methods [5]. In this regard, the region needs to intensify land management practices in order to improve land productivity per unit area since it affects tree husbandry.

The size of the land has a total reflection to the number of trees planted. More than 45 respondents in each district reported to have their own trees except Moshi Muncipality wherein only 17 respondents reported having own trees (Table 5). As stated earlier, most of respondents in Moshi Municipality are living in rented houses and tenants frequently change houses, hence commitment by this group to plant trees on the premises they live is limited. About $61 \%$ of all respondents owned 50 trees and below. Same, Siha and Rombo districts had relatively higher number of respondents who own 201 trees and more compared to other districts (Table 5). This is an indication that scarcity of land in these three districts is relatively less compared to other districts. Same and Rombo districts had large number of respondents (50\% and 38\% respectively) who had land specifically set aside for tree planting while Hai (11\%) and Siha (1\%) had lowest. Respondents from Mwanga, Moshi Rural and Moshi Municipal reported to have no specific area for tree planting because of insufficient land. Instead, they were mixing trees with other agricultural crops and other trees are planted in borders. Therefore access and ownership/land tenure were considered as factors affecting tree husbandry in the region.

\subsubsection{Cultural Factors}

Every society has its own socio-cultural factors which members of the society conforms to. These factors are important because a member of the society needs to know them in order to participate in various activities [17]. These socio-cultural factors can influence both men and women in a particular society. Though some of the factors cannot be explained scientifically, still the members of the society honour them. Results from this study revealed that, cultural factors, to some extent, affect tree husbandry in some districts of the region. 55\%, $26 \%$, $10.5 \%$ and $8 \%$ of all respondents from Hai, Same, Rombo and Moshi Municipal respectively agreed that cultural issues could be considered as one of factors affecting tree husbandry in Kilimanjaro region. However, all respondents in Siha, Mwanga and Moshi Rural totally disagreed that cultural issues influences tree planting and management. Table 6 is an activity profile showing how culturally the society has allocated various activities to both women and men in tree growing. The profile shows that there are activities which are performed by men and others by women. However, when women perform activities which are associated with men, they are doing them on behalf of men but not on their own. Additionally, it was reported that some tree species like Euphorbia triculli and Albizia coriaria are not allowed to be grown by women. It is alleged that if a woman plants such tree species, she will become barren and her husband will die [18]. Generally, all activities in tree growing are done by men except weeding and watering which are done by women. The allocation of duties is discriminating against women. Therefore cultural aspects limit participation of women in afforestation and agro-forestry programs. Results from this study agree with the findings of Chavangi [18], that certain tree species may have culturally defined gender specific and ownership restrictions.

\subsubsection{Legal Issues}

About 23.4\%, 30\% and 40.8\% of respondents in Same, Hai and Rombo districts respectively agreed that there are some by-laws which compel people to plant trees on the areas surrounding their environments. Very few percentages of respondents in Siha and Moshi Municipal agreed on the same (Table 7). The by-laws reported to compel people to plant trees including; planting of trees surrounding their areas, restrictions on cutting trees unnecessarily, planting trees in catchments and lowlands, restrictions on cutting tree without a permit, prohibiting unnecessary setting of fire and grazing animals in some areas. Some posters were observed in some areas of Hai and Same prohibiting cutting of trees unnecessarily, unnecessary setting of fire and prohibition on grazing of animals. Most of the by-laws are enforced by village, ward, and division officials. There are prescribed punishments for those who fail to abide by-laws and regulations. The kind of punishments reported includes verbal warning and fines. The findings further pointed out a number of complaints from various individuals regarding violation of existing by-laws by some of the officials in wards and villages including few dishonest forest offi- 
Table 5. Number of respondents within each tree category, Kilimanjaro region, Tanzania.

\begin{tabular}{|c|c|c|c|c|c|c|}
\hline \multirow{2}{*}{ District } & \multicolumn{5}{|c|}{ Number of respondents by tree category } & \multirow[t]{2}{*}{ Total } \\
\hline & $1-50$ & $51-100$ & $101-200$ & $201-500$ & $\geq 501$ & \\
\hline Hai & 33 & 12 & 2 & 2 & 2 & 51 \\
\hline Siha & 28 & 19 & 2 & 9 & 1 & 59 \\
\hline Same & 29 & 5 & 7 & 3 & 6 & 50 \\
\hline Mwanga & 41 & 8 & 4 & 2 & 2 & 57 \\
\hline Rombo & 26 & 8 & 13 & 7 & 4 & 58 \\
\hline Moshi Rural & 33 & 7 & 2 & 3 & 1 & 46 \\
\hline Moshi Municipal & 17 & 0 & 0 & 0 & 0 & 17 \\
\hline Total & 207 & 59 & 30 & 26 & 16 & 338 \\
\hline$\%$ & 61.2 & 17.5 & 8.9 & 7.7 & 4.7 & \\
\hline
\end{tabular}

Table 6. Activity profile for women and men in tree growing, Kilimanjaro region, Tanzania.

\begin{tabular}{|c|c|c|c|}
\hline \multirow{2}{*}{ Activities } & \multicolumn{3}{|c|}{ Who does it? } \\
\hline & Men & Females & Both \\
\hline Preparation for the holes for transplanting tree seedlings & $\mathrm{X}$ & & \\
\hline Site selection where tree seedlings are planted & $\mathrm{X}$ & & \\
\hline Types of tree seedlings to be planted & $\mathrm{X}$ & & \\
\hline Actual planting of trees & $\mathrm{X}$ & & \\
\hline Weeding of tree seedlings & & $\mathrm{X}$ & \\
\hline Watering of tree seedlings & & $\mathrm{X}$ & \\
\hline Protecting the tree seedlings from destruction by putting protective devices & $\mathrm{X}$ & & \\
\hline Pruning of trees & $\mathrm{X}$ & & \\
\hline
\end{tabular}

Table 7. Number of respondents who agreed that legal issues insist people to plant trees in their areas in Kilimanjaro region.

\begin{tabular}{ccc}
\hline Districts & Number of Respondents & Percentage of Respondent \\
\hline Hai & 36 & 30.0 \\
Siha & 1 & 0.8 \\
Same & 28 & 23.4 \\
Rombo & 49 & 40.8 \\
Moshi Municipal & 6 & 5.0 \\
Total & 120 & 100 \\
\hline
\end{tabular}

cials. Similar weaknesses have been observed in other areas in Africa [19]. Respondents from Mwanga and Moshi Rural districts, however, reported that they are unaware of the by-laws. Probably this unawareness explains why most of the respondents from these two districts owned few number of tress i.e. below 50 trees (Table 5).

\subsubsection{Capacity Building}

A high number of respondents in Hai (22\%) and Rombo (23\%) districts agreed that they have ever been trained on tree planting and tending. However, respondents though few in number; $7 \%, 8 \%, 12.5 \%, 13 \%$ and $15 \%$ in Moshi Municipal, Mwanga, Same, Siha and Moshi Rural districts respectively agreed to have been trained on tree planting and tending. More training is needed especially in Moshi Municipal and Mwanga districts. Some respondents from Rombo, Siha and Same districts reported to have never been trained by any institution but they know how to plant and tend trees from their parents. Some institutions reported to train people on tree planting and tending and issues concerning environmental conservation includes Hai Green Initiative (HGI), Kilimanjaro 
National Park Authority (KINAPA), TENGERU, Sustainable Land Management Project (SLM), Foresters and environmentalists from Districts, Community Development Officers from Districts, Selian-Arusha, Tanzania Association of Foresters (TAF), Tanzania Forestry Research Institute (TAFORI), GTZ, PADEP and TASAF.

\subsubsection{Labour Availability}

None of the respondent from any district reported to employ any casual labour to assist in tree farm establishment and management. All the respondents reported to attend tree planting activities such as tree farm establishment, tree planting and tending on their own. This is because most of respondents do not have land specifically set aside for tree planting. Instead, trees are mixed on banana and coffee farms and on farm boundaries. Therefore, labour availability is not one of the factors affecting tree husbandry in Kilimanjaro region.

\subsubsection{Other Factors}

1) Insects and Diseases

Insect pests and diseases were among other factors affecting tree husbandry in Kilimanjaro region. Other pests reported to affect trees were livestock and human beings that destroy young trees especially near the roads. Rombo was the leading district in insect pests and diseases infestation while Moshi Rural was the least (Table 8). Insect pests and diseases infest the stressed trees which are weak. Some parts of Rombo, Same and Mwanga districts get insufficient rain which cannot sustain the growth of trees. The mean annual rainfall of Rombo and Mwanga districts are 500 and $400 \mathrm{~mm}$ (in lowland) respectively [22] [23]; In this case most of trees in these areas are stressed, hence prone to insects and diseases attack. Siha and Moshi Rural districts had shown low infestation of insect pests and diseases compared to other districts probably because of sufficient rain. The mean annual rainfall of Siha and Moshi Rural are about 900 and 800 mm [20] [21].

2) Climate

Large number of respondents from Siha (19.3\%), Rombo (17.2\%), Moshi Rural (16.8\%), Mwanga (14\%) and Hai $(13.7 \%)$ reported that the existing climate allows good growth of most planted trees species. $10.5 \%$ and 8.8\%, relatively few number of respondents in same and Moshi Municipal respectively, agreed that the existing climate does allow good growth of most planted trees species. Some respondents from Same and Mwanga reported a long period of drought and strong dry wind in lowland limit tree growth while respondents from Rombo reported stunted growth during strong cold season as the climatic factors hindering tree husbandry. Same and Mwanga districts are located in the semi-arid areas in Kilimanjaro region and they experiences 400 - $600 \mathrm{~mm}$ of rainfall per annum in low lands [22]. Temperatures range between an average of $14^{\circ} \mathrm{C}$ during June-July and $32^{\circ} \mathrm{C}$ usually during the month of January therefore tree growth and other agricultural crops are affected much by changing climate in these districts.

\section{Conclusions and Recommendations}

Factors affecting tree husbandry in Kilimanjaro region in Tanzania include access and ownership/land tenure, cultural issues, by-laws, capacity building, age, gender and education. Other factors are insect pests, diseases

Table 8. Insects and diseases reported to affect tree growth in Kilimanjaro region.

\begin{tabular}{|c|c|c|c|c|}
\hline Districts & $\begin{array}{l}\text { Number of } \\
\text { Respondents }\end{array}$ & $\begin{array}{l}\text { Percentage of } \\
\text { Respondent }\end{array}$ & Insects & Disease \\
\hline Hai & 14 & 11.7 & Termites, ants, white flies, catarpillars & $\begin{array}{l}\text { Rotting of roots of Grevillea, } \\
\text { frost, dropping of leaves }\end{array}$ \\
\hline Siha & 7 & 5.8 & Termites & Die back, heart rot \\
\hline Same & 20 & 16.7 & Termites & Die back, leaf spot \\
\hline Mwanga & 20 & 16.7 & $\begin{array}{l}\text { White flies, stem boares, } \\
\text { termites, fruit boers }\end{array}$ & Damping off, die back, heart rot \\
\hline Rombo & 50 & 41.7 & Termites, ants, white flies, catarpillars, & Frost \\
\hline Moshi Rural & 1 & 0.8 & Termites & Leaf spots \\
\hline Moshi Municipal & 8 & 6.7 & Spider, white flies, termites & \\
\hline Total & 120 & 100.0 & & \\
\hline
\end{tabular}


and climate change. It is therefore recommended that; strict implementation of by-laws in tree planting in the districts that are lagging behind, so that people can plant trees and reduce land degradation; insisting in the use of agro-forestry practices whereby agricultural crops are mixed with trees because of insufficient of land in the region; educating the community members to change their attitudes towards cultural factors which promote tree growing and conduct a study on the best way of controlling pests and diseases affecting tree husbandry in Kilimanjaro region.

\section{Acknowledgements}

Authors gratefully acknowledge the Government of Tanzania, Global Environment Facility (GEF) and UNDP through Sustainable Land Management (SLM) Project in Kilimanjaro for financing this study. Authors are also indebted to all Institutions and individuals who facilitated the study. Finally, the authors are thankful to the Project Technical Team from Project Coordination Unit (PCU) at the RAS-Kilimanjaro Office for their useful comments and suggestions.

\section{References}

[1] United Republic of Tanzania (URT) (1998) National Forest Policy. Government Printer, Dar-es-Salaam, 59 p.

[2] Akida, A. and Blomley, T. (2006) Trends in Forest Ownership, Forest Resources Tenure and Institutional Arrangements: Are They Contributing to Better Forest Management and Poverty Reduction? Case Study from Tanzania. Unpublished Report, FAO, Rome.

[3] United Republic of Tanzania (URT) (2001) National Forestry and Beekeeping Programme, 2001-2010. Forestry and Beekeeping Division, Ministry of Natural Resources and Tourism, 132 p.

[4] Ngaga, Y.M. (2011) Forest Plantations and Woodlots in Tanzania. African Forest Forum. Nairobi, 76 p.

[5] United Republic of Tanzania (URT) (1998) Kilimanjaro Region Social-Economic Profile. The Planning Commission, Dar es Salaam and Regional Commissioner’s Office, Kilimanjaro, 230 p.

[6] United Republic of Tanzania (URT) (2013) 2012 Population and Housing Census. National Bureau of Statistics, Ministry of Finance, Dar es Salaam and Office of Chief Government Statistician President’s Office, Finance, Economy and Development Planning, Zanzibar, 244 p.

[7] TAFORI (2010) Production and Consumption of Fuel Wood and Tree Species Preferences in Kilimanjaro Region. TAFORI Project Report, Moshi Timber Research Centre, Moshi, 21 p.

[8] Mugo, F.W. (2001) The Role of Woodfuel Conservation in Sustainable Supply of the Resource: Paper Presented at Charcoal Stakeholders. ICRAF Working Paper No. 20, Nairobi.

[9] Kimaryo, B.T. and Ngereza, K.I. (1993) Development and Promotion of Improved Traditional Earth Kilns for Charcoal Production in Kilimanjaro Region of Tanzania. A Consultancy Report Submitted to REDPU/MWEM, Dar es Salaam. A World Bank/IDA Supported Project, TAFORI, Morogoro.

[10] Sangeda, A.Z., Kahimba, F.C., Kashaga, R.A.L., Semu, E., Mahonge, C.P. and Mkanda, F.X. (2014) Testing of Decision Making Tools for Village Land Use Planning and Natural Resources Management in Kilimanjaro Region. Open Journal of Soil Science, 4, 446-458.

[11] Lovett, J.C. and Pócs, T. (1993) Assessment of the Condition of the Catchment Forest Reserves, a Botanical Appraisal. Report Prepared for the Catchment Forestry Project.

[12] Lovett, J.C. (1993) Eastern Arc Moist Forest Flora. In: Lovett, J.C. and Wasser, S.K., Eds., Biogeography and Ecology of the Rain Forest of Eastern Africa, Cambridge University Press, Cambridge, 35-56. http://dx.doi.org/10.1017/cbo9780511895692.004

[13] Valentine, G. (1997) Tell Me about Using Interviews as a Research Methodology. In: Flowerdew, E. and Martin, D., Eds., Methods in Human Geography: A Guide for Students Doing a Research Project, Longman, London, 110-253.

[14] Lema, T.A. (2003) The Role of Non-Timber Forest Products in Household Food Security and Women Income in Morogoro Rural District, Tanzania. Master's Dissertation, Sokoine University of Agriculture, Morogoro.

[15] Raphael, T. and Swai, G. (2009) The Impact of Participatory Forest Management and Local People’s Perceptions on Its Implementation at the Village Level in Mufindi Districts, Southern Tanzania Highlands. Proceedings of the First Participatory Forest Management (PFM) Research Workshop: Participatory Forest Management for Improved Forest Quality, Livelihood and Governance, Morogoro, 15-16 December 2008, 133-146.

[16] Lebora, H. (2006) Contribution of Participatory Forest Management to Sustainable Forest Management and Poverty Reduction in Lindi Rural District, Tanzania. Master's Dissertation, Sokoine University of Agriculture, Morogoro, 3650 . 
[17] Oloo, J.O., Makenzi, P.M., Mwangi, J.G. and Abdulrazack, A. (2013) Influence of Traditions/Customs and Beliefs/ Norms on Women in Tree Growing in Siaya County, Kenya. Global Journal of Environmental Science and Technology, 1, 1-6.

[18] Chavangi, N. (1984) Cultural Aspects of Fuel Wood Procurement in Kakamega District, Kenya. Working Paper No. 4, Kenya Fuel Wood Development Program/Beijer Institute, Nairobi.

[19] Anderson, A.B., May, P.H. and Balick, M.J. (1991) The Subsidy from Nature: Palm Forests, Peasantry, and Development in Amazon Countries. Columbia University Press, New York.

[20] Moshi District Council (2011) Moshi District Socio-Economic Profile. MoDC, Moshi, 22 p.

[21] Siha District Council (2013) Siha District Socio-Economic Profile. SDC, Siha, 93 p.

[22] Mwanga District Council (2011) Mwanga District Socio-Economic Profile. MDC, Mwanga, 19 p.

[23] Rombo District Council (2013) Rombo District Socio-Economic Profile. RDC, Rombo, 54 p. 


\section{Appendix I. Factors Affecting Tree Husbandry and Woodlots Establishment in Kilimanjaro Region, Tanzania}

\section{RESPONDENT'S GENERAL INFORMATION}

District name

Ward name

1.1. Name

1.2. Sex Male $\square \quad$ Female

1.3. Education attained

1.4. Marital status: Married Separated
The interview date

Village/Suburb/Street name

Age

Years

Unmarried $\square \quad$ Divorce $\square$ Widow
Widower $\square$

1.5. Occupation: (1) Peasant (2) Livestock keeper (3) Peasant \& Livestock keeper

(5) Others state

\section{ACCESS AND OWNERSHIP/LAND TENURE}
2.1. Do you use firewood?
Yes
2.2. Do you use charcoal for energy?
Yes
No
No

2.3. If yes please state the source of your firewood/charcoal

2.4. Do you own trees?

Yes

No $\square$

2.5. If yes how many trees do you have?

2.6. Why don't you have more trees than what you have mentioned?

2.7. What are the tree species do you have and what are their uses?

2.8. What are the uses of the tree species that you have?

2.9. What is the growth status of your trees? Good

2.10. If not good what are the main problems?

2.11. Do you own land?

Yes $\square \quad$ No $\square$

2.12. If yes state how many hectares/acres

2.13. Have you set aside land for tree planting? Yes $\square$ No $\square$

2.14. If yes state how many hectares/acres

2.15. If no state why

2.16. Where do you get seeds for tree planting exercise

2.17. Where do you get seedlings for tree planting exercise?

2.18. What are your tree species preferences?

2.19. Please give reasons for their preference

\section{CULTURAL ISSUES}

3.1. Are there any cultural issues affecting land ownership? $\quad$ Yes $\square \quad$ No

3.2. If yes state

3.3. How do they affect land ownership?

Yes

No $\square$

3.4. Are there any cultural issues affecting tree farm establishment?

Yes

No

3.5. If yes state

3.6. How do they affect tree farm establishment?

\section{LEGAL ISSUES}

4.1. Are there any laws which insist you to plant trees on area around you? Yes

4.2. If yes state

4.3. If yes, have you followed the law?

4.4. If no, can you give reasons for not following the law?

\section{CAPACITY BUILDING}

5.1. Have you ever been trained on tree planting? $\quad$ Yes $\square \quad$ No $\square$ 
5.2. If yes mention the organization involved in providing that training.

\subsection{Have you ever been trained on tending of trees? $\quad$ Yes $\square \quad$ No}

5.4. If yes mention the organization involved in providing that training

\section{LABOUR AVAILABILITY}

6.1. Have you employed any casual labourer to assist you in tree farm establishment? Yes 6.2. If yes how many casual labourers do have?

6.3. What are the main duties/activities does the casual labourers assist you?

6.4. Are casual labourers readily available? Yes

No

6.5. If yes, where/how do you get them?
6.6. Do you pay them?
Yes
No

6.7. If yes, how much do you pay them per day/week/month?

6.8. Can scarcity of casual labourers affect establishment and tending of trees in your farm? Yes

\section{OTHERS}

7.1. Is there any disease that affects growth of your trees?

Yes $\square \quad$ No

7.2. If yes state type of disease

7.3. Is there any insect that affects growth of your trees?

Yes

No

7.4. If yes state type of insects

7.5. Does the climate allow good growth of your trees?

Yes

No

7.6. If no state why

7.7. What should be done in order to speed up tree planting? 